\title{
Case for Climate Smart Agriculture in Addressing the Threat of Climate Change
}

\author{
John Saviour Yaw Eleblu, Eugene Tenkorang Darko, and \\ Eric Yirenkyi Danquah
}

\section{Contents}

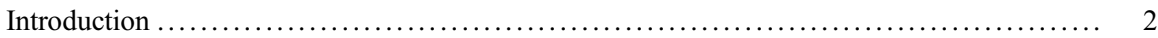

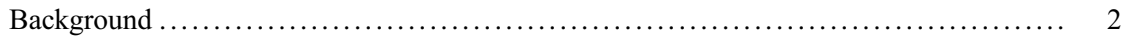

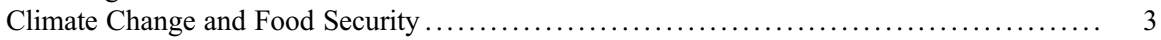

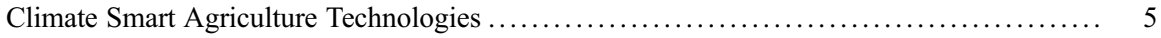

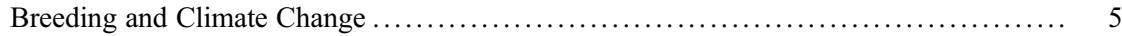

Efficient Resource Management ......................................... 7

Integrated Renewable Energy Technologies of Farming Systems ................... 9

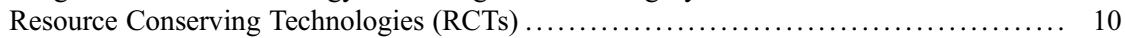

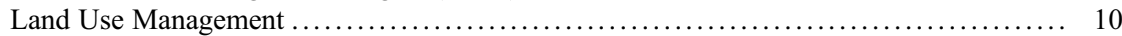

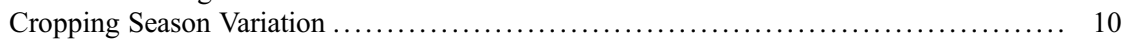

Crop Relocation ..................................................... 11

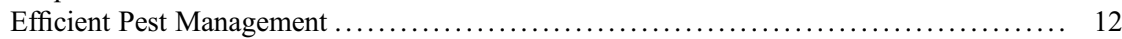

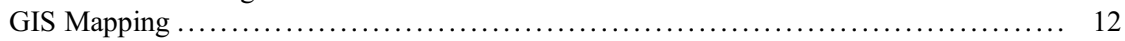

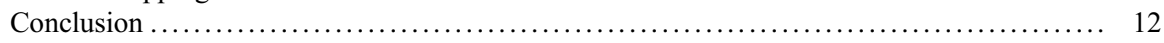

References $\ldots \ldots \ldots \ldots \ldots \ldots \ldots \ldots \ldots \ldots \ldots \ldots \ldots \ldots \ldots \ldots \ldots \ldots \ldots \ldots \ldots \ldots \ldots \ldots \ldots \ldots \ldots \ldots \ldots, 13$

\section{Abstract}

Climate smart agriculture (CSA) embodies a blend of innovations, practices, systems, and investment programmes that are used to mitigate against the adverse effects of climate change and variability on agriculture for sustained food

This chapter was previously published non-open access with exclusive rights reserved by the Publisher. It has been changed retrospectively to open access under a CC BY 4.0 license and the copyright holder is "The Author(s)". For further details, please see the license information at the end of the chapter.

J. S. Y. Eleblu $(\bowtie) \cdot$ E. Y. Danquah

West Africa Centre for Crop Improvement, University of Ghana, College of Basic and Applied Sciences, Accra, Ghana

E. T. Darko

Geography and Resource Development, University of Ghana, Legon, Ghana 
production. Food crop production under various climate change scenarios requires the use of improved technologies that are called climate smart agriculture to ensure increased productivity under adverse conditions of increased global temperatures, frequent and more intense storms, floods and drought stresses. This chapter summarizes available information on climate change and climate smart agriculture technologies. It is important to evaluate each climate change scenario and provide technologies that farmers, research scientists, and policy drivers can use to create the desired climate smart agriculture given the array of tools and resources available.

\section{Keywords}

Climate change $\cdot$ Climate $\cdot$ Climate smart agriculture $\cdot$ Food security $\cdot$ Breeding approaches

\section{Introduction}

\section{Background}

Climate describes the weather conditions of a region such as its temperature (hot, warm, or cold) which is due to amounts or intensity of sunshine, rainfall (dry or wetness) and its pattern, air pressure, humidity, cloudiness, and wind, throughout the year, averaged over a series of years. "Climate change" as a terminology was suggested by the World Meteorological Organization (WMO) in 1966 to represent climate variations over long periods of time often from decades to millennia, irrespective of the causative agents (Hulme 2017). The term has been widely accepted and has fast become a household name for climatic variations which are often not favorable for man's survival. Climate change has largely been associated with anthropogenic global warming; however, it is indeed larger and encompasses all vagaries in climatic conditions which occur over decades. Also human activities are estimated to have caused approximately $1.0^{\circ} \mathrm{C}$ of global warming above pre-industrial levels, with a likely range of $0.8^{\circ} \mathrm{C}$ to $1.2{ }^{\circ} \mathrm{C}$. Global warming is likely to reach $1.5^{\circ} \mathrm{C}$ between 2030 and 2052 if it continues to increase at the current rate (IPCC 2018). In today's world, the term climate change has evolved from being a technical jargon for describing vagaries in climatic pattern into a global issue agent which requires the intervention of man to prevent future disastrous outcomes being predicted.

It should be noted that this book chapter will cover very limited information on climate change as the objective is to guide the reader to appreciate the need for a response that adopts innovations to accelerate the development of climate smart agriculture technologies as mitigation efforts against climate change. With that understanding we shall proceed to attempt to cover the breadth of knowledge in a summary of what is known with regards to the expected impact of climate change on crop production and food security, an overview of climate smart agriculture technologies and what is possible given current trends in technology and innovation.

Even though mitigation and adaptation responses compete with each other due to potential negative trade-offs across spatial, temporal, institution (Smith and Olesen 
2010), economic scales (Wilbanks and Sathaye 2007). While mitigation measures aim to reduce emissions on a global scale, adaptive measures are specific to microenvironments and address various local impacts of climate change. As a result of the interconnection between the environment and socio-economic risks, the agriculture sector offers opportunities for complementary actions through the implementation of ecosystem sensitive approaches known as the CSA. This new approach is to bridge the growing divide between the two discourses and foster long-term resilient development in the agriculture sector. CSA is defined by FAO as "agriculture that sustainably increases productivity, resilience (adaptation), reduces/removes GHG's (mitigation) and enhances achievement of national food security and development goals' (FAO 2010). Therefore, adaptation, mitigation, and food security are the three key pillars of CSA (Lipper et al. 2014).

Climate smart agriculture (CSA) is a way to achieve sustainable development as well as green economy goals. It intends towards food availability and takes part to conserve natural assets and is closely associated with perception of improved growth, as FAO develops it for crop yield (FAO 2011). There is a high need for climate smart agriculture because agricultural production systems are expected to produce food for a global population of about 9.1 billion people in 2050 and over 10 billion by the end of the century (UNFPA 2011). This, however, has necessitated the development of CSA strategies and policies at different levels of governance (Zougmore et al. 2016). Therefore, it is highly imperative to sustain livelihoods which are predominantly agrarian in these regions.

\section{Climate Change and Food Security}

Climate change has the potential to threaten food production and, consequently, food security especially in vulnerable regions. One major area where the impact of climate change is expected to be very significant in threatening the very existence of humanity is the estimated effect of climate change on agriculture. Agriculture is the major source of income and livelihood for an estimated $70 \%$ of the poor and vulnerable people who live in rural areas with limited resources oftentimes without access to basic technologies (World Bank 2016b). However, the production of food is being affected by climate change, it is therefore important to study the influence of this global climate change to meet the requirements of people and is estimated that by 2100 , the world population will reach about 10 billion (Boogaard et al. 2014). The climate change and variability will adversely impact on food security and agriculture livelihoods of the poorest farmers, fisher folks and forest dwellers. Even though sub Saharan Africa contributes less than 5\% of the global greenhouse gas (GHG) emissions, the region is vulnerable to the negative effects of climate change due to the fact that the region's development prospects are closely linked to the climate due to the great reliance on rainfall (Tol 2018). Added to other nonclimatic stresses (poverty, inequality, and market shocks), the impact of climate change will make negatively impede the achievement of the Sustainable Development Goals (SDGs) on livelihoods, food security, poverty reduction, health, and access to clean water in vulnerable communities (IPCC 2014a). However, the use of 
climate change predictions based on theories and past data accrued over centuries is difficult to use in projecting the expected impact of changing climates on food security. Since the institution of climate change as a body or a field of study, many academic and scientific publications have emerged. The first scientific work by Katz, published in the first issue of the first journal on climate change titled "Climate Change" on the effect of climate change on food production clearly questioned the accuracy of any such predictions and warned that the predicted impacts at the time were estimates should be acknowledged as such. A direct quote from Katz follows: "Attempts to assess the impact of a hypothetical climatic change on food production have relied on the use of statistical models which predict crop yields using various climatic variables. It is emphasized that the coefficients of these models are not universal constants, but rather statistical estimates subject to several sources of error. Thus, any statement regarding the estimated impact of climatic change on food production must be qualified appropriately" (Katz 1977).

The aforementioned challenges have been addressed by leading investigators recently where climate change impact has been modelled based on quick countrylevel measurement of vulnerability to food insecurity under a range of climate change and adaptation investment scenarios (Richardson et al. 2018). The findings have been made accessible through their publication and an online interactive portal that is user friendly for policymakers (Met Office 2015). The interactive graphically displayed model predicts that food insecurity vulnerability is anticipated to worsen rapidly under all simulations of GHG emissions, and the re-distribution of vulnerable geographic regions remains very similar to present-day conditions where subSaharan Africa and South Asia remain the most severely affected. By the year 2050, an additional 2.4 billion people expected to be living in developing countries with much concentration in South Asia and sub-Saharan African, where agriculture is an important sector and major employment source, but currently more than $20 \%$ of the population is on average food insecure (Wheeler and von Braun 2013). About 75\% of the global poor live in rural areas, and agriculture is their most important source of income (International Fund for Agricultural Development 2011). High levels of adaptation is seen to be able to decrease vulnerability across affected areas; however, the only scenario with the highest level of mitigation combined with high levels of adaptation shows appreciable levels of reduction in vulnerability compared to the present-day prevailing conditions (Smith and Olesen 2010). As agriculture is directly affected by climate change, adaptation strategies are becoming increasingly important issues for promoting development (Clements et al. 2011). Therefore, adaptation strategies in the context of climate change are all those practices that are employed by smallholder farmers to either get used to or minimize the effects of climate change and variability. According to the IPCC, adaptation is the process of adjustment to actual or expected climate and its effects that in human systems, adaptation seeks to moderate or avoid harm or exploit beneficial opportunities (IPCC 2014). The strategies for adapting to climate change and variability can be grouped into two; namely, autonomous and planned adaptation strategies. The autonomous adaptation strategies involve actions taken by non-state agencies such as farmers, communities, or organizations and/or firms in response to climatic shocks while planned adaptation involves actions taken by local, regional, and or 
national government to provide infrastructure and institutions to reduce the negative impact of climate change. However, the planned adaptation which measures or results from deliberate policy decisions and awareness from farm to global levels and are discussed in literature as key to reducing present and future vulnerability and climate impacts on livelihoods (IPCC 2014). However, there are limitations to planned adaptation measures under severe conditions. As a result, more systematic changes in adaptive capacity and resource allocation are being considered. So in this discussion we shall look at the various climate smart agriculture practices that can help mitigate the climate change effects on agriculture. Therefore, the effects of climate change can be solved by climate smart agriculture practices such as climate smart crop (breeding), improved pasture and animal rearing, amelioration of degraded lands, rehabilitation of polluted water bodies, and management of sustainable systems such as agroforestry, livestock management, and manure management. Also, the promotion of sustainable land management practices which are also part of CSA practices (Branca et al. 2011) have influenced paradigms shift from the traditional practices. Most of these technologies can help mitigate greenhouse gasses (GHG) emissions. Food security and improving food productivity can also reduce human vulnerability to climate impacts and the need for additional land conversion to agriculture, which represents almost as much as GHG emissions and those directly generated from agriculture activities (IPCC 2014), but food production and security measures may conflict with climate smart and conservation objectives, especially intensifying agriculture and producing more food for a growing population (Matocha et al. 2012).

\section{Climate Smart Agriculture Technologies}

The climate smart agriculture technologies will focus on describing some of the approaches which include breeding (climate smart crop), efficient resource management, integrated renewable energy technologies for farming systems, resource conserving technologies, land use management, cropping season variation, efficient pest management, forecasting, and geographic information system (GIS) mapping.

\section{Breeding and Climate Change}

Agriculture was born about 13,000 years ago when man gradually transitioned from hunting and gathering lifestyle into domestication of wild plants and animals. Food production systems since the invention of Agriculture which remains heavily dependent on the availability of rainfall has been evolving progressively to match-up to the growing demands of the human population. It is noteworthy that the art of breeding which emerged through domestication which involved selecting plants and animals that were acceptable with good qualities for the consumption/utilization by man. Breeding which begun as selection has seen many advancements; notable are hybridization techniques, matting designs and schemes, genetics enhanced hybridization programs, tissue culture and mutagenesis aided systems, genetic engineering 
using recombinant DNA technologies, and Genomics- and other Omics-assisted breeding and the latest being genome editing. A summary of the resources and tools available for breeders in this day and age is presented in Box 1 below. As breeding has evolved based on man's knowledge and the development of tools to aid the development of new variants, climate and the rate of climate change has rapidly outpaced and outstripped the worlds production systems especially in areas of greatest vulnerability where new technologies remain inaccessible. The dry areas and flood prone areas are of the greatest concern where extreme weather conditions can prevail and persist for long periods disrupting the natural seasons and cycles of production that farmers are used to. These concerns can mostly be addressed if all tools available to breeders are widely accepted and utilized to aid in the development of climate smart crops that are designed to adapt to harsh and extreme weather conditions producing higher yields compared to currently available varieties that do poorly under such conditions.

\section{Box 1 Array of Tools and Resources Available to Breeders}

Genetic Genetic Resource 1st Generation 2nd Generation 3rd Generation 4th Generation Resources Characterization Breeding Tools

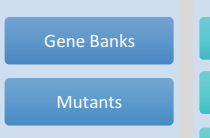

Core Collections

Diverse Panels

Bi-Parental QTL

Recombinant

Recombinant
Inbred Lines

Nested Association Mapping Population

MAGIC

Training Populations
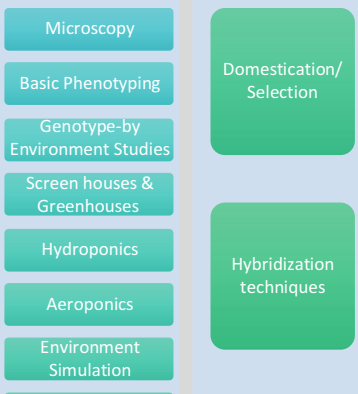

Live imaging
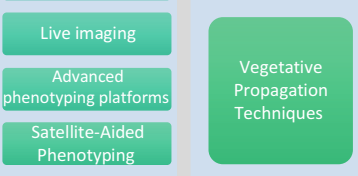
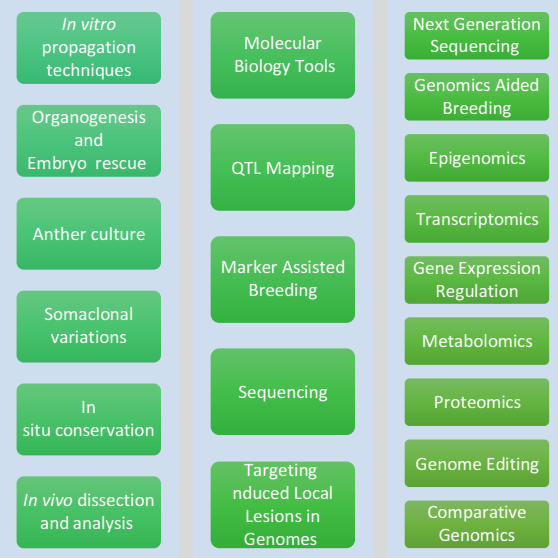

The myriad of available resources range from genetic resources available that are conserved in situ, ex situ, or in vitro; gene banks, core and representative collections not forgetting diverse panels in national, international, and regional research Centres as well as the Bi-parental, Recombinant Inbred Lines (RILs), Nested Association Mapping, Multi-parent Advanced Generation Inter-cross (MAGIC) \& Training 
populations in the hands of researchers and Scientists who originated and curated them. These genetic resources are sources of alleles of great agronomic importance required in the development of climate smart crops or animal breeds that can withstand and yield highly under changing climatic conditions. These are therefore the first range of arsenals of breeders in the fight against dwindling productivity under climate change conditions. The next in the array of tools are those that can be used to characterize, evaluate, detect, select, and then release these climate adaptable varieties to farmers and businesses for increasing productivity under prevailing circumstances. These tools have evolved from first generation to the current cutting edge fourth generation tools that are available for breeders to use in the development of new and improved varieties with better adaptation to the changing environmental conditions. The first-generation tools mainly encompass discoveries of basic principles of domestication/selection, the knowledge and use of pollination to make self and crosses as well as means of vegetative propagation such as grafting, corms, bulbs etc. Second generation array of tools are mainly based on advances in biology that allow for cell, tissue and organ culture which allow for more advanced technologies in the crop and animal improvement by breeders. Third and fourth generation tools such as represented in Box 1 that have been developed add speed and precision to the array of tools that are currently available for quick development of improved climate smart crops.

It is important to evaluate each climate change scenario and provide strategies breeders can use to create the desired climate smart crops given the array of tools and resources available. The various climate change scenarios, potential impact and climate smart breeding approaches are delineated in Table 1. For instance, climate change is greatly impacting agriculture currently in the tropics and other arid areas with erratic rainfalls that no longer follow the patterns or established seasons known to farmers that heavily depend on rain-fed crop production systems. This scenario has the potential impact of poor yields as a consequence of untimely start of the farming activities and crop failure. For adaptability to such scenarios, climate smart crops with adaptability to different types of droughts or erratic rains could be developed using a combination of tools and resources described in Box 1 and made available to farmers. Such climate smart crops are required in vulnerable areas threatened by climate change in order to avert the worsening food insecurity problem and ensure the achievement of sustainable development goals 1 (no poverty) and 2 (no hunger).

\section{Efficient Resource Management}

Another approach that can be of relevance in achieving the objectives of climate smart agriculture is efficient management of resources. This approach is an important part of CSA and the future environment. In the food production chain, from the farmer to the customer or final consumer, almost one third part of the food is lost due to the improper management of resources (Hartter et al. 2017). On yearly basis, for instance, the total energy consumption in the global food losses are almost $38 \%$ of all 
Table 1 Climate change scenarios, potential impact, and climate smart breeding approaches

\begin{tabular}{l|l|l}
\hline $\begin{array}{l}\text { Climate change } \\
\text { scenarios }\end{array}$ & Potential impact & Climate smart approaches \\
\hline Erratic rainfall & $\begin{array}{l}\text { Farmers plant too late or too } \\
\text { early leading to yield losses }\end{array}$ & $\begin{array}{l}\text { Climate smart crops with } \\
\text { adaptability to different types of } \\
\text { droughts or erratic rains. }\end{array}$ \\
\hline $\begin{array}{l}\text { Prolonged droughts in } \\
\text { arid areas and New } \\
\text { Droughts prone areas }\end{array}$ & $\begin{array}{l}\text { Crop losses, Famine and loss of } \\
\text { lives }\end{array}$ & $\begin{array}{l}\text { Drought resistant crops that } \\
\text { perform well under water limited } \\
\text { conditions }\end{array}$ \\
\hline $\begin{array}{l}\text { Increased floods } \\
\text { Damage to crops and animals; } \\
\text { storms }\end{array}$ & $\begin{array}{l}\text { Development of water loving } \\
\text { crops as well as crops resistant to } \\
\text { lisplacement of people }\end{array}$ \\
\hline Rise in sea levels & $\begin{array}{l}\text { Damage to crops and animals } \\
\text { loscrease in salt stress on crops, } \\
\text { levels of salts, low or no yields }\end{array}$ & None \\
\hline Loss of soil cover & $\begin{array}{l}\text { Soil erosion, loss of soil fertility, } \\
\text { loss of microbes in the soil }\end{array}$ & $\begin{array}{l}\text { Planting of trees and plants that } \\
\text { will rehabilitate the soils. } \\
\text { Introduction of bioengineered } \\
\text { microbes that encourage soil } \\
\text { health. }\end{array}$ \\
\hline $\begin{array}{l}\text { Increased global } \\
\text { temperatures }\end{array}$ & $\begin{array}{l}\text { Reduced yields, new pests and } \\
\text { disease emergence and damage } \\
\text { to crops and animals }\end{array}$ & Improved heat adaptable crops \\
\hline
\end{tabular}

the energies utilized by the food chain. Critical areas in the food chain processes which serve as good avenues for improving energy efficiency includes: transportation, conservation, processing, cooking, and consumption (FAO 2011). In Africa, a majority of wood removed is used for manufacturing household articles as well as cooking. However, cooking in stoves helps save energy thereby decreasing deforestation in the long run. For instance, this technique of managing resources and climate change projects has helped in supporting sustainable intensification through a number of initiatives including the establishment of an agriculture information and the decision support system and the preparation of soil management plans. Since this approach was adopted in 2014, climate smart agriculture was adopted on 2,946,000 hectares and has provided for a carbon sequestration potential of up to 9 million tons carbon dioxide annually, (https://www.worldbank.org/en/topic/climate-smart-agri culture). Additionally pastoralists are also enjoying some benefits from climate smart agriculture in the Sahel, Burkina Faso, Chad, Mali, Mauritania, Senegal, and Niger. The application of rangeland management is boosting productivity and resilience. This approach is also helping to reduce emissions. 


\section{Integrated Renewable Energy Technologies of Farming Systems}

The Integrated Renewable Energy Technologies is the application of suitable energy technologies, tools, and different farming services which are relevant in creating the stable change to energy smart proficient food systems. These technologies are governed by conditions of nature. These technologies are very useful because in the long run there will be a reduction in GHG's emissions. For instance, mid-season aeration can be promoted through short term drainage. Some of the technologies in the energy smart food system are the windmills, solar panels, wind generators, photovoltaic lights, biogas, and conversion of hydrothermal tools, bio energy and water pumping machines, information and communication technological innovation, and other similar approaches (Bochtis et al. 2014; Basche 2015). This technology has been applied in Morocco through the Morocco inclusive project Green Growth project, through the supply of agrometeorological information and the facilitation of the resilience building technology such as direct seeders. The pumps used can be both fuel and electric water pumps which are mostly used on irrigation farming (deep well and submersible pumps). Stakeholders in the agricultural industry should appreciate this modern technological innovation due to the benefits of increasing the value of production in the farming business. Most times, these technologies are linked on the farm from an integrated food energy system as shown in Fig. 1 below.

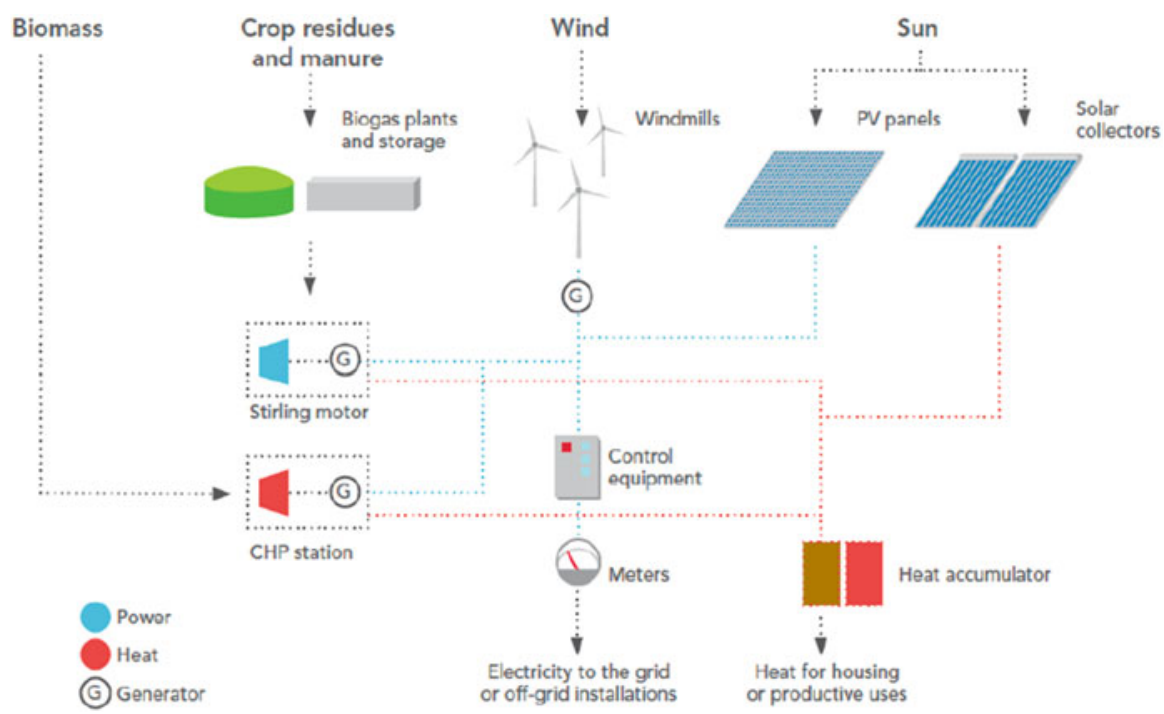

Fig. 1 Integrated renewable energy technologies for farming systems. (Source: Amin et al. 2016) 


\section{Resource Conserving Technologies (RCTs)}

This technology consists of methods that enhance efficiency in the management of inputs. When these resource technologies are implemented, it comes with its own merits which includes low cost of productivity, limited use of fuel, labor, water, and early planting of crops which results in improved yields in the long run. For instance, the zero tillage system, which happens to be one of the resource conserving technologies, is a type of cultivation system in which the seeds are directly sowed into a virgin (uncultivated) soil. The zero-tillage system, however, involves the cultivation of crops into untilled soil by aeration of thin channels with adequate depth-width so as to attain suitable seed coverage. The soil remaining is left as if tillage has never been done on it before (Derpsch et al. 2010). In some parts of the globe, the zero tillage permits farmers to grow wheat very soon after the rice harvest. This allows the head of the crops to appear and the filling of the grains before the warm weather, pre-monsoon set off. Therefore, as the average temperature of the globe in certain parts rises, early planting will be more relevant for the production of wheat (Pathak 2009).

\section{Land Use Management}

Land use management involves the proper planning of land and its usage. The proper planning includes fixing the location of plants and livestock production, changing the concentration of the application of plant foods and bug sprays can reduce global warming on agricultural activities (Ahmad et al. 2014). Other land use practices involve shifting production out of marginal areas, changing the role of applying cartilage and pesticides. However, it must be noted that capital and labor can minimize the risks from Climate change on agriculture production. The farmers can regulate the duration of the growing season by changing the time at which the farming fields are sown. Other adaptation mechanisms can be in the form of changing the times of irrigation and use of fertilizer.

Figure 2 elucidates Cropland Expansion Potential for different continents.

\section{Cropping Season Variation}

The planting dates can be set to reduce the infertility that is caused by increasing temperatures; this may prevent the flowering period from meeting with the hot period (Arslan et al. 2015). The effects of the increased climatic variations which normally happens in both the semiarid and arid regions sometimes take advantage of the wet period by changing the planting times/dates. However, this approach is usually to avoid intense weather events in the growing season. This system of cultivation promotes the development of strong cultivars thereby leading to the production of different crops. The planting dates can be set to reduce the infertility that is caused by increasing temperature; this may prevent the flowering period from meeting with the hot period. The effects of the increased climatic variations which 


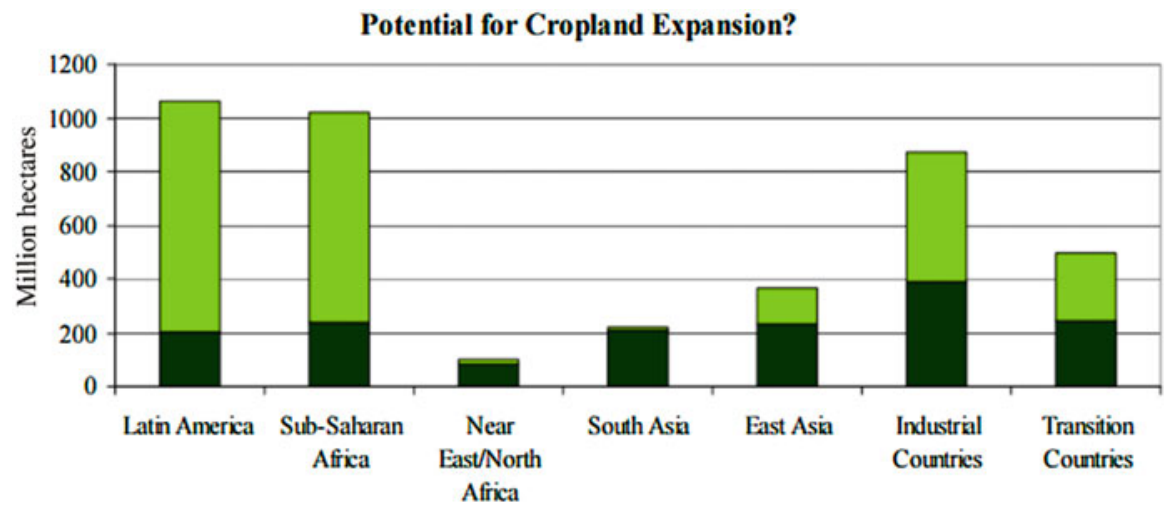

Region
- Arable land in use, $2005 \square$ Additional land with rainfed crop production potential

Fig. 2 Land use management. (Source: Burnisma 2009)

normally happens in both the semiarid and arid regions sometimes take advantage of the wet period by changing the planting times/dates. However, this approach is usually to avoid intense weather events in the growing season. This system of cultivation promotes the development of strong cultivars thereby leading to the production of different crops. The farmers will, therefore, need to ensure that they adopt the changing crop rotation system in the various hydrological cycles (Pathak et al. 2012).

\section{Crop Relocation}

This approach involves the grouping and sorting of the plants and the varieties with respect to its sensitivity to the weather condition of a place. Crop relocation helps the crops to perform well according to the sensitivity of the climate during the vegetative and productive stages (Shames et al. 2012). There are several factors which affect agricultural production as a result of climatic change. These include increase in temperature, carbon dioxide $\left(\mathrm{Co}_{2}\right)$ levels, and increase in drought and floods. These impacts vary across the various regions in the world as well as the different cultures. Other factors such as daylight, temperature, and humidity are very necessary for the vegetative and reproductive growth of the crops. Additionally the period for harvesting should be properly done so as to minimize losses during the period (Baba et al. 2017). However, it is therefore important to differentiate regions and crops that are highly susceptible to climate change. For instance, it is obvious that temperature increases affect the quality of many important crops. Some of these crops with respect to the discussion include basmati rice and tea. 


\section{Efficient Pest Management}

The normal agriculture pest and insect management on farms poses a threat to the environment. The usage of chemicals to destroy and kill pests is very harmful for farmers and also living organisms in the soil. Even chemicals such as insecticide, herbicides for plant diseases have been banned by some governments of certain countries, as the situation exists now, there is no botanical or environmental friendly chemical available. Due to this, farmers still use the chemicals for controlling pests on their farms. So, basically this technique provides an opportunity to employ environmentally friendly measures for pest control. The difference in the climatic factors such as the fall and rise in temperature unpredictably influences pest and disease incidence thereby impacting on major crops.

Therefore, the change in climate will affect the relationship of pest and weed and the host populations. However, some of the adaptation strategies in this pest management approach includes;

(i) Improvement in different breeding types that are resistant to pest and disease.

(ii) Strong pest adaptation mechanism with more relevant control for both biological and cultural practices.

(iii) Adoption of techniques such as crop substitution with regards to places resistant to pest and hazards.

\section{GIS Mapping}

This approach is used in analysis and mapping. It is a system which is designed to capture, store, manipulate, analyze, manage, and present geographical data. However, it helps in the estimation and computation of storm causes and flooding that is related to hot cyclones. The study in using GIS mapping considers factors such as property allocation, infrastructure facilities among other resources. The photograph and images (Fig. 3) were used in the experimentation of seashore due to rising sea levels and hot cyclones. The figure below shows risk which can be explained by the cumulative study of emerging threat and the existing patterns of vulnerability. The technique enables the creation of hazards and risk maps at many different possible scales or dimensions to show the threat allocation across different geographical spaces within the globe. Some of the geographical places can be site specific, municipal (administrative areas) and other natural landscapes in river basins, coastlines, and lakes. Figure 3 portrays Mapping and Risk Assessment.

\section{Conclusion}

Climate change is a great threat to agriculture and as such there is the need to tackle this adverse impact by adopting new innovative techniques in climate smart agriculture. This chapter has dealt with some of the climate smart agriculture techniques 


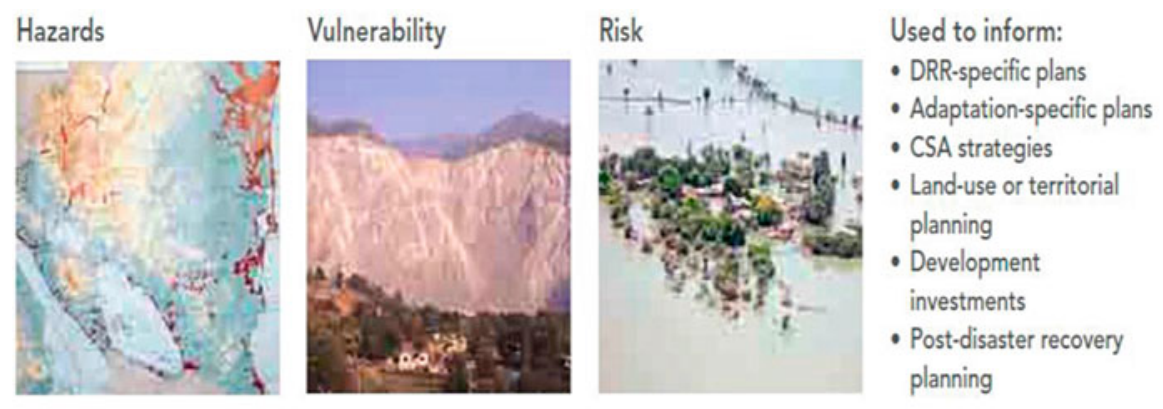

Photo Credits:

Hazards - Republic of Nicaragua, Direccion de Hidrologia Superficial Vulnerability - OFAO, Thomas Hofer Risk - @FA0, Truls Brekke

Fig. 3 Risk Assessment and mapping. (Source: Amin et al. 2016)

that can help reduce the impacts of climate change on agriculture and increase food crop production. To achieve food security and agriculture development goals, adaptation to climate change will be required to lower emission intensities per output. Thus improving food protection by moderate climate change, sustainable use of the natural resources, using all products more competently, have less inconsistency and greater constancy in their outputs. More fruitful and more flexible agriculture requires a paramount change in the usage of resources such as land, water, soil nutrients, and genetic resources management by climate smart agriculture approaches.

\section{References}

Ahmad MI, Ali MA, Khan SR, Hassan SW, Javed MM (2014) Use of crop growth models in agriculture: a review. Sci Int 26(1):331-334, Lahore

Amin A, Mubeen MHM, Nasim W (2016) Climate Smart agriculture: an approach for sustainable food security. Agriculture Research Communications 3:13-21

Arslan A, Mccarthy N, Lipper L, Asfaw S, Cattaneo A, Kokwe M (2015) Climate smart agriculture? Assessing the adaptation implications in Zambia. J Agric Econ 66(3):753-780

Baba RA, Owiyo T, Barbie B, Denton F, Rutabingwa F, Kiema A (2017) Advancing climate-smart agriculture in developing drylands: joint analysis of adoption of multiple on-farm soil and water conservation technologies in West African Sahel. Land Use Policy 61(2):196-207

Basche AD (2015) Climate -smart agriculture in Midwest cropping systems: evaluating the benefits and trade-offs of cover crops. PhD Dissertation, Iowa State University

Bochtis DD, Sorensen CGC, Busato P (2014) Advances in agricultural machinery management: a review. Biosyst Eng 126(10):669-681

Boogaard H, De Wit A, Te Roller J, Van Diepen C (2014) Wofost control centre; users guide for the Wofost control centre and the crop growth simulation model Wofost 7. Alterra, Wageningen

Branca G, Mccarthy N, Lipper L, Jolejole MC (2011) Climate smart agriculture: a synthesis of empirical evidence of food security and mitigation benefits from improved cropland 
management. Retrieved from http://www.fao.org/climatechange/ 297640aa5796a4fb093b6cfdf05558.pdf.

Burnisma J (2009) The resource outlook to 2050: By how much to land, water use and crop yields need to increase by 2050. Expert meeting on how to feed the world in 2050. FAO and ESDD, Rome, $\mathrm{p} 33$

Clements R, Haggar J, Quezada A, Torres J (2011) In: Zhu X (ed) Technologies for climate change adaptation-adaptation sector. UNEP Riso Centre, Roskilde

Derpsch R, Friedrich T, Kassam A, Li H (2010) Current status of adoption of no till farming in the world and some of its main benefits. Int J Agric Biol Eng 3:1-25

FAO (2010) Climate- smart agriculture: policies, practices and financing for food security, adaptation and mitigation. Food and Agriculture Organization of the United Nations, Rome

FAO (2011) The state of food and agriculture 2010-11. In: Women in agriculture: closing the gender-gap for development. Food and Agriculture Organisation of the United Nations, Rome

Hartter J, Hamilton LC, Boag AE, Stevens FR, Ducey MJ, Christo ND, Palace MW (2017) Does it matter if people think climate change is human caused? Clim Serv 10(4):53

Hulme M (2017) Climate change, concept of. Int Encycl Geogr People Earth Environ Technol 16. https://doi.org/10.1002/9781118786352.wbieg0343

IPCC (2014a) Climate change: impacts, adaptation and vulnerability. Part A: Global and sectoral aspects. Contribution of working group II to the fifth assessment report for the intergovernmental panel on climate change. Cambridge University Press, Cambridge, UK/New York

IPCC (2014b) Chapter 7: Food security and food production systems. In: Climate change 2014: impacts, adaptation, and vulnerability. IPCC working group II contribution to AR5. IPCC Secretariat, World Meteorological Organization, Geneva. Available: http://ipccwg2.gov/ images/uploads/WGIIARS5-Cha

IPCC (2018) Summary for policymakers. In: Global warming of $1.5^{\circ} \mathrm{C}$. An IPCC special report on the impacts of global warming of $1.5^{\circ} \mathrm{C}$ above pre-industrial levels and related global greenhouse gas emission pathways, in the context of strengthening the global response to the threat of climate change, sustainable development and efforts to eradicate poverty [V. Masson-Delmotte, P. Zhai, H. O. Pörtner, D. Roberts, J. Skea, P. R. Shukla, A. Pirani, W. Moufouma-Okia, C. Pean, R. Pidcock, S. Connors, J. B. R. Mathews, Y. Chen, X. Zhou, M. I. Gomis, E. Lonnoy, T. Maycock, M. Tignor, Waterfield (eds)]. World Meteorological Organization, Geneva, 32p

Katz RW (1977) Assessing the impact of climatic change on food production. Clim Chang 1:85-96

Lipper L, Thornton P, Campbell BM, Baedeker T, Braimoh A, Bwalya M, Torquebiau EF et al (2014) Climate- smart agriculture for food security. Nat Clim Chang 4:1068-1072. https://doi. org/10.1038/nclimate2437

Matocha J, Schroth G, Hills T, Hole D (2012) Integrating climate change adaptation and mitigation through agroforestry and ecosystem conservation. In: Nair PKR, Garrity D (eds) Agroforestry-the future of global land use. Springer, Dordrecht, pp 105-126

Met Office (2015) Food insecurity and climate change model spread. Retrieved from http://www. metoffice.gov.uk/food-insecurity-index

Pathak H (2009) Agriculture and environment. In: Handbook of agriculture. Directorate of Information and Publication Agriculture, ICAR, New Delhi, pp 62-92

Pathak H, Aggarwal PK, Singh SD (eds) (2012) Climate change impact, adaptation and mitigation in agriculture: methodology for assessment and applications. Indian Agricultural Research Institute, New Delhi, p 302

Richardson KJ et al (2018) Food security outcomes under a changing climate: impacts of mitigation and adaptation on vulnerability to food insecurity. Clim Chang. https://doi.org/10.1007/s105840182137-y

Rural Poverty Report (2011) International fund for agriculture development

Shames S, Wollenberg E, Buck LE, Kristjanson P, Masiga M, Biryahaho B (2012) Insitutional innovations in Africa smallholder carbon projects. CCAFS Report No. 8. Copenhagen, CCAFS

Smith P, Olesen J (2010) Synergies between the mitigation of, and adaptation to climate change in agriculture. J Agric Sci 148:54-552. https://doi.org/10.1017/S0021859610000341 
Tol RSJ (2018) The economic impacts of climate change. Rev Environ Econ Policy 12:4-25

UNFPA (2011) Annual Report: Delivering Results in a World of 7 billion, New York

WB (2016a) World Data Bank -agriculture indicators. The World Bank, Washington, DC. Assessed 05 June 2020

WB (2016b) World Data Bank-agriculture indicators. The World Bank, Washington, DC. Accessed 05 June 2018

Wheeler T, von Braun J (2013) Climate change impacts on global food security. Science 341:508-513

Wilbanks T, Sathaye J (2007) Integrating mitigation and adaptations responses to climate change: a synthesis. Mitig Adapt Strateg Glob Chang 12(5):957962. https://doi.org/10.1007/ s110270079108*3

Zougmore R, Partey S, Ouedraogo M, Omitoyin B, Thomas T et al (2016) Toward climate-smart agriculture in West Africa:a review of climate change impacts, adaptation strategies and policy developments for the livestock, fishery and crop production sectors. Agriculture and Food Security $5(1): 26$

Open Access This chapter is licensed under the terms of the Creative Commons Attribution 4.0 International License (http://creativecommons.org/licenses/by/4.0/), which permits use, sharing, adaptation, distribution and reproduction in any medium or format, as long as you give appropriate credit to the original author(s) and the source, provide a link to the Creative Commons license and indicate if changes were made.

The images or other third party material in this chapter are included in the chapter's Creative Commons license, unless indicated otherwise in a credit line to the material. If material is not included in the chapter's Creative Commons license and your intended use is not permitted by statutory regulation or exceeds the permitted use, you will need to obtain permission directly from the copyright holder.

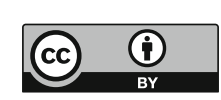

